Wahana Fisika, 3(1), 2018. 88 - 92

http://ejournal.upi.edu/index.php/wafi

e-ISSN : 2594-1989

\title{
Studi Deposisi Lapisan Tipis ZnO Menggunakan Teknik Dip-Coating
}

\author{
Yayah Kuriah * , Iwan Sugihartono \\ Universitas Negeri Jakarta (UNJ), Jl. Rawamangun Muka Jakarta 13220, \\ Indonesia \\ * Penulis Penanggungjawab. E-mail: yayahkuriaah@gmail.com \\ Telp/hp: 081260150007
}

\begin{abstract}
ABSTRAK
Telah dilakukan studi deposisi lapisan tipis $\mathrm{ZnO}$ menggunakan teknik DipCoating (Teknik Celup) diatas material kaca yang merupakan salah satu material yang diduplikasikan sebagai kaca ITO pada sel surya. Lapisan tipis $\mathrm{ZnO}$ dibuat dengan cara sol-gel yang mencampurkan beberapa material kedalamnya sehingga didapatkan sol-gel ZnO. Pada penelitian ini dilakukan beberapa variasi celup yaitu dua kali dan empat kali celup. Deposisi lapisan tipis $\mathrm{ZnO}$ diatas kaca preparat. Berdasarkan hasil karakterisasi menggunakan difraksi sinar-X diperoleh bahwa lapisan yang dihasilkan merupakan amorf. Pada variasi celup kedua dan keempat didapatkan bentuk amorf dari lapisan tipis $\mathrm{ZnO}$ tersebut.
\end{abstract}

Kata Kunci: Lapisan Tipis ZnO; Sol Gel ZnO; Dip Coating; Difraksi Sinar-X; Studi Deposisi 


\begin{abstract}
$\mathrm{ZnO}$ thin film deposition has been done using Dip-Coating technique on glass material which is one of the materials that is duplicated as ITO glass in solar cell. A thin layer of $\mathrm{ZnO}$ is made by sol-gel which mixes several materials into it to obtain $\mathrm{ZnO}$ sol-gel. In this research, there are several variations of dye that is twice and four times the dye. Deposition of a thin film $\mathrm{ZnO}$ over a glass preparation. Based on the characterization results using X-ray diffraction obtained that the resulting layer is amorphous. In the second and fourth dip variations obtained the amorphous form of the $\mathrm{ZnO}$ thin film.
\end{abstract}

Keywords: Thin Film ZnO; Sol Gel ZnO; Dip Coating; X-Ray Diffraction; Deposition Study

\section{Pendahuluan}

Indonesia merupakan negara yang berpotensi besar untuk menjadikan sel surya sebagai sumber energi masa depan, posisi Indonesia yang jatuh tepat pada garis khatulistiwa memungkin sinar matahari dapat optimal menyinari seluruh wilayah Indonesia. Terlebih lagi Indonesia merupakan negara beriklim tropis yang hanya mempunyai 2 musim, yaitu musim kemarau dan musim hujan. Sel surya yang sekarang banyak dikembangkan adalah Dye Sensitized Solar Cell, yaitu sel surya yang terbuat dari semikonduktir yang dilapisi zat warna untuk meningkatkan efesiensi konversi sinar matahari. Didalam DSSC terdapat empat bagian antara lain: Kaca ITO (Indium Tin Oxide) sebagai substrat, $\mathrm{TiO}_{2}$ sebagai bahan semikonduktor, Dye alami sebagai donor elektron dan elektrolit sebagai transfer elektron [1].

ITO sendiri berfungsi sebagai substrat kaca transparan konduktif. Dimana ITO sebagai badan dari sel surya dan lapisan konduktifnya berfungsi sebagai tempat muatan mengalir. Keunggulan ITO adalah merupakan campuran dari $\mathrm{SnO}_{2}$, dan $\mathrm{In}_{2} \mathrm{O}_{3}$ adapun perbandingan $\mathrm{Sn}$ : In sekitar 5 : 95. Keunggulan ITO adalah resistivitasnya rendah, tetapi proses pembuatan In sangat mahal. Oleh karena itu pada saat ini dikembangkan lapisan tipis lainnya untuk lapisan konduktif transparan [2].

Salah satunya adalah pengembangan lapisan tipis $\mathrm{ZnO}$. Lapisan tipis $\mathrm{ZnO}$ sudah banyak digunakan pada berbagai campuran kombinasi seperti pada piezoelektrik, listrik, optik dan sifat panas. $\mathrm{ZnO}$ 
adalah material semikonduktor tipe-n golongan II-IV dengan lebar band gap 3,20 eV pada suhu kamar. Selain itu, $\mathrm{ZnO}$ emmiliki sifat emisi yang dekat dengan sinar UV, fotokatalis, konduktivitas dan transparasi yang tinggi. Bahan ini digunakan sebagai bahan dasar lapisan tipis karena memiliki beberapa keunggulan dalam aplikasinya, terutama dalam bidang sensor, sel surya, serta nanodevice. Banyak cara untuk membuat lapisan tipis $\mathrm{ZnO}$ baik secara alami maupun didoping seperti deposisi uap kimia, sputtering, spray pirolisis dan proses sol gel [3].

$\begin{array}{ccc}\text { Kristal adalah zat padat yang } \\ \text { susunan } & \text { atom-atomnya atau }\end{array}$
molekulnya teratur. Partikel kristal tersusun secara berulang dan teratur serta perulangannya mempunyai rentang yang panjang. Struktur kristal terdapat pada hampir semua logam dan mineral. Suatu struktur kristal dibangun oleh sel unit, sekumpulan atom yang tersusun secara khusus, yang secara periodik berulang dalam tiga dimensi dalam satu kisi. Jarak antar sel unit dalam segala arah disebut parameter kisi. Struktur dan simetri suatu zat padat mempunyai peran penting dalam menentukan sifatsifatnya, seperti band gap dan sifat optik lainnya $[4,5]$.
Dalam penelitian ini dibuat lapisan tipis $\mathrm{ZnO}$ menggunakan metode dip coating, denngan variasi pencelupan yaitu dua kali dan empat kali. Berdasarkan hasil deposisi lapisan tipis $\mathrm{ZnO}$ selanjutnya ditentukan bagaimana karakterisasi kristal yang terbentuk dari metode tersebut. Karakterisasi kristal $\mathrm{ZnO}$ diamati menggunakan X-Ray difractometer (XRD) [6].

\section{Bahan dan Metode}

Zinc Acetate Dehydrate $\left(\mathrm{Zn}\left(\mathrm{CH}_{3} \mathrm{COO}\right)\right.$ 2. $\left.2 \mathrm{H}_{2} \mathrm{O}\right)$ dipilih sebagai bahan baku pembuatan lapisan tipis $\mathrm{ZnO}$. Bahan baku ini dlarutkan dengan Deionized Water (DI Water) dan Monoethanolamine (MEA). Rasio molar dari MEA dan ZnAc adalah 1:1 dan konsentrasi ZnAc adalah 0,6 mol/ L. Kemudian dimasukan kedalam 15 $\mathrm{ml}$ Isopropanol alcohol. Larutan distirrer dan dipanaskan pada suhu 60 ${ }^{\circ} \mathrm{C}$ selama 4 jam sampai larutan menjadi bening dan homogen. Setelah larutan menjadi homogen maka larutan didiamkan semalaman dalam suhu ruang sebelum digunakan untuk pencelupan.

Persiapkan kaca preparat dengan ukuran (35 mm x $25 \mathrm{~mm} \mathrm{x} 1 \mathrm{~mm}$ ). Sebelum digunakan kaca harus dibersihkan dengan DI water selama 5 


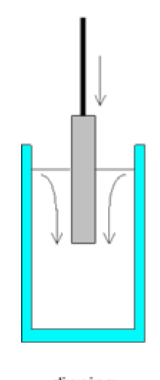

dipping

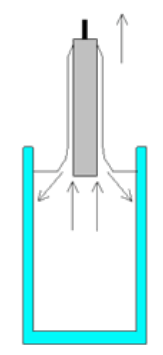

wet layer formation

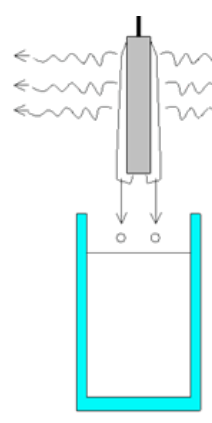

solvent evaporation

Gambar 1. Proses Dip-Coating

menit menggunakan ultrasonic cleaner, kemudian kaca dibersihkan kembali dalam ultrasonic cleaner dengan isopropanol alcohol selama 10 menit.

Setelah semua persiapan selesai maka proses dip coating dimulai. Pencelupan dilakukan dengan kecepatan dan kedalaman yang sama. Dalam penelitian ini dilakukan pencelupan dan pengangkatan kaca selama empat kali pengulangan. Proses dip coating dilakukan dengan kecepatan $1 \mathrm{~mm} /$ menit. 15 menit.
Setelah proses dip coating selesai maka lapisan tipis dipanaskan pada suhu $225 \square$ selama 15 menit. Lapisan tipis $\mathrm{ZnO}$ yang dihasilkan kemudian dikarakterisasi untuk mengetahui struktur lapisannya menggunakan XRay difractometer (XRD).

\section{Hasil dan Pembahasan}

Karakterisasi menggunakan X-Ray diffraction (XRD) terhadap sampel lapisan tipis $\mathrm{ZnO}$ memberikan

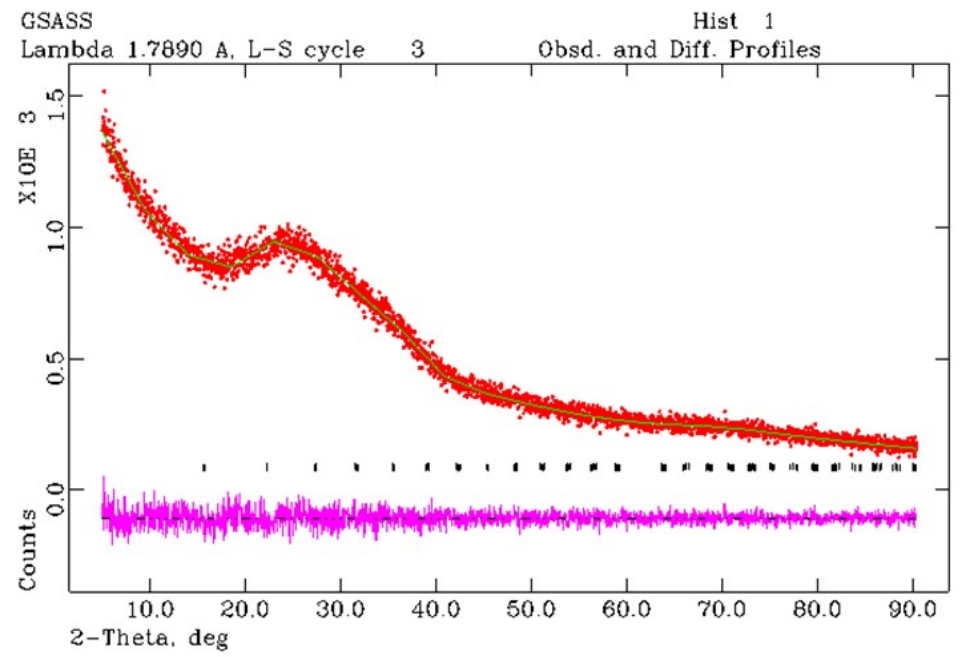

Gambar 2. Hasil XRD 4 Kali Pencelupan 
Pola difraksi XRD dari lapisan tipis $\mathrm{ZnO}$ dengan pencelupan selama empat kali diperlihatkan pada gambar. Pada gambar tersebut tidak terlihat adanya puncak difraksi. Hal ini menunjukkan lapisan tipis $\mathrm{ZnO}$ bersifat amorf. Hasil karakterisasi menggunakan XRD dengan variasi pencelupan dua dan empat kali menghasilkan pola yang serupa dengan pola difraksi pada gambar. Dengan demikian lapisan tipis $\mathrm{ZnO}$ pada substrat kaca merupakan struktur amorf.

\section{Simpulan}

Berdasarkan hasil dan pembahasan diatas, maka dapat disimpulkan bahwa lapisan tipis $\mathrm{ZnO}$ pada kaca preparat menggunakan teknik dip coating dengan dua kali dan empat kali pencelupan tidak menunjukan adanya puncak tajam pada posisi sudut tertentu. Dari hasil tersebut dapat dikatakan bahwa deposisi lapisan tipis $\mathrm{ZnO}$ pada kaca preparat merupakan amorf.

\section{Ucapan Terima Kasih}

Ucapan terima kasih kepada Program Studi Fisika Universitas Negeri Jakarta atas bantuan yang diberikan dalam bentuk dana maupun fasilitas labotarium.

\section{Referensi}

1. Siswanto, B., Wirjoadi, \& Yunanto. (2007). deposisi Lapisan Tipis (CdS) Tipe-N diatas Lapisan Tipis (CuInSe2) Tipe-P Sebagai Penyangga Untuk Sel Surya CIS. GANENDRA, Vol X.

2. Saleh, W. R., Saeed, N. M., Twej, W. A., \& Alwan, M. (2012). Synthesis Sol-Gel Derived Highly Transparent $\mathrm{ZnO} \mathrm{m}$ Thin Films for Optoelectric Applications. Scientificn Research , 11-16.

3. Setiawan, A., Murti, H., Aliah, H., \& Winata, T. (2013). Laju Deposisi dan Celah Pita Energi Optik Lapisan Tipis a-Si:H yang Ditumbuhkan dengan Teknik HWC-VHF-PECVD. Prosiding Semirata FMIPA Universitas Lampung .

4. Yuliah, Y., \& Suryaningsih, S. (2016). Penentuan Ukuran Nanopartikel $\quad \mathrm{ZnO}$ secara Spektroskopik. Prosiding Seminar Nasional Fisika (E-Journal) .

5. Wang, Z. L. (2004). Zinc Oxide Nanostructures: Growth, Properties and Applications. Journal of Physics: Condensed Matter, R829-R858.

6. Purwanto, A., Ratnasari, D., \& Suryono, A. B. (2014). Pembuatan Nanopartikel Seng Oksida ( $\mathrm{ZnO})$ Menggunakan Proses Flame Assisted Spray Pyrolisis (FASP). Ekuilibrium , 17-21. 